\title{
The spatial and temporal distribution of heavy metals in sediments of Victoria
}

\section{Harbour, Hong Kong}

Chloe Wing-yee Tang ${ }^{\mathrm{a}}$, Carman Ching-man Ip ${ }^{\mathrm{a}}$, Gan Zhang ${ }^{\mathrm{b}}$, Paul, K.S. Shin ${ }^{\mathrm{c}}$, Pei-yuan

$$
\text { Qian }{ }^{\mathrm{d}} \text {, and Xiang-dong } \mathrm{Li}^{\mathrm{a}, *}
$$

${ }^{a}$ Department of Civil \& Structural Engineering, The Hong Kong Polytechnic University, Hung Hom, Kowloon, Hong Kong

${ }^{b}$ State Key Laboratory of Organic Geochemistry, Guangzhou Institute of Geochemistry, Chinese Academy of Sciences, Guangzhou 510640, China

${ }^{\mathrm{c}}$ Department of Biology and Chemistry, City University of Hong Kong, Tat Chee Avenue, Kowloon, Hong Kong

${ }^{\mathrm{d}}$ Department of Biology \& Coastal Marine Laboratory, Hong Kong University of Science and Technology, Clear Water Bay, Kowloon, Hong Kong

\section{Abstract}

Victoria Harbour has received substantial loadings of pollutants from industrial and municipal wastewater discharged since the 1950s. Inputs of contaminants have declined dramatically during the last two decades as a result of better controls at the source and improved wastewater treatment facilities. To assess the spatial and temporal changes of metal contaminants in sediments in Victoria Harbour, core and grab sediments were collected. The central harbour areas were generally contaminated with heavy metals. The spatial distribution of trace metals can probably be attributed to the proximity of major urban and industrial discharge points, and to the effect of tidal flushing in the harbour. In the sediment cores, the highest concentrations of trace metals were observed to have accumulated during the 1950s to 1980s, corresponding with the

\footnotetext{
* Corresponding author. Tel.: + 852-2766-6041; Fax: + 852-2334-6389.

E-mail address: cexdli@polyu.edu.hk (X.D. Li).
} 
period of rapid urban and industrial development in Hong Kong. From the late 1980s, there has been a major decline in the concentrations of trace metals, due to a reduction in industrial activities and to the enactment of wastewater pollution controls in the territory. The $\mathrm{Pb}$ isotopic compositions of the sediments revealed the anthropogenic inputs of $\mathrm{Pb}$ to the harbour. The ${ }^{206} \mathrm{~Pb} /{ }^{207} \mathrm{~Pb}$ ratios varied from 1.154 to 1.197 , which were lower than those of background geological materials in Hong Kong $\left({ }^{206} \mathrm{~Pb} /{ }^{207} \mathrm{~Pb}\right.$ : 1.201-1.279). The data also indicated that the $\mathrm{Pb}$ in the harbour sediments most likely originated from mixed sources, including the leaded gasoline used in the past and other anthropogenic sources.

Keywords: Trace metals; Pb isotopes; Sediment; Historical sources; Victoria Harbour; Hong Kong

\section{Introduction}

Victoria Harbour is located in the southeastern part of the Pearl River Estuary (PRE) in south China. It is a major port of Hong Kong, and lies between the most urbanized areas of the Kowloon Peninsula and the northern shore of Hong Kong Island. The harbour has strong tidal flushing, whereby seawater flows from the east at Lei Yue Mun Channel to west of the harbour during flood tides, and in the opposite direction during ebb tides. Water in the harbour is further influenced by discharges of freshwater from the PRE in the west (Morton and Wu, 1975). Victoria Harbour has been subjected to significant environmental pollution from increasing urban and industrial development in the last few decades. The major sources of pollution include municipal wastewater, urban runoff, and industrial effluents. In 1995, the harbour received an estimated 1.5 
million tonnes of sewage and industrial wastewater every day (Hong Kong Government, 1995). As a consequence, there was a rapid decline in the quality of the water in the harbour, as bacteria, organic materials, and other pollutants seriously affected fish and other marine life by depleting oxygen levels in the water (Yung et al., 1999). However, the input of contaminants to Victoria Harbour has been greatly reduced in recent years, due to enhanced efforts to control the problem at the source, improved wastewater treatment facilities, and increased public awareness (HKEPD, 2004).

Once contaminants are released into the aquatic environment, they may be removed from the water column by interacting with suspended solids and subsequently be deposited as bottom sediments (Croudace and Cundy, 1995). Coastal sediments are considered to be a major sink for, and also a secondary source of pollutants. The fate of contaminants in sediments depends on a number of factors, including the resuspension, bioturbation, and diagenesis of sediments (Bothner et al., 1998; Lee and Cundy et al., 2001). Heavy metals, unlike other pollutants, are not biodegradable and can accumulate in sediments over time. The contamination of metals in sediments can reach a level that is toxic to aquatic life. Metals that have accumulated in sediment profiles can also act as a historical record of human activities in a watershed and provide insight on the accumulation of metal contaminants over time (Finney and Huh, 1989).

Sedimentation rates and sediment chronology in sediment cores are now commonly estimated by the ${ }^{210} \mathrm{~Pb}$ dating technique. This dating technique has proven to be successful for determining dates back to about 100 years and is widely used in coastal marine, estuarine, and marsh environments (i.e., Hornberger et al., 1999; Bay et al., 2003; Ip et al., 2004). As a common metal contaminant, stable Pb isotopes have frequently been used to identify different sources of lead in the environment (Sturges and Barrie, 1987; Erel et al., 2001; Zhu et al., 2001). Anthropogenic Pb is derived from 
lead sulfide ore deposits and is released into the environment through the combustion of leaded gasoline and as a byproduct of industrial $\mathrm{Pb}$ use. In general, the $\mathrm{Pb}$ in most ore bodies is less radiogenic and has a lower ${ }^{206} \mathrm{~Pb} /{ }^{207} \mathrm{~Pb}$ ratio than that found in most natural bedrock. The inherited differences in $\mathrm{Pb}$ isotopic signatures between natural and anthropogenic $\mathrm{Pb}$, thus allow $\mathrm{Pb}$ isotopic compositions to be used to identify $\mathrm{Pb}$ sources and, in some cases, to provide source apportionment for potential sources of $\mathrm{Pb}$ (Farmer et al., 1996).

A number of previous research projects have focused on studying trace metals in surface sediments of Victoria Harbour. The sediments in Victoria harbour have been found to be highly contaminated with $\mathrm{Cu}, \mathrm{Zn}, \mathrm{Cr}$, and $\mathrm{Pb}$ due to the discharge of untreated industrial waste and sewage since the 1960s (Yim, 1981; Wong et al., 1995; HKEPD, 2003). Metals in the sediments of the harbour have also been found to induce toxic effects in fish and algal bioassays (Wong et al., 1995; Wong et al., 2000). Over the last two decades, measures aimed at improving the environment, such as the enactment of the Water Pollution Ordinance, the introduction of unleaded petrol, the operation of a chemical waste treatment centre, and the implementation of the Harbour Area Treatment Scheme (HATS) have resulted in a reduction in the amount of metals being discharged into Victoria Harbour (HKEPD, 2000). However, there have been very few studies focusing on the changes in the metal contaminants in sediments due to such a reduction. It is of importance to assess the changes in the contamination of sediments over time, particularly the recent two decades. The present study aims to study the current contamination of trace metals and the historical fluxes of metals in Victoria Harbour, and to evaluate the potential sources of metal pollutants based on the geochemical features and $\mathrm{Pb}$ isotopic compositions in the sediments. 


\section{Methodology}

\subsection{Sediment sampling}

Five sampling sites from east (B1) to west (B5) of Victoria Harbour were selected for collecting core and grab sediments (Figure 1). Grab surface sediments were collected in Victoria Harbour during the four cruise outings in December 2004, February 2005, October 2005, and April 2006, respectively, to provide representative data on the spatial distribution of trace metals in the harbour. Core sediments were collected in October 2004 and used for the study of the temporal distribution of metals in the profiles. These locations have good coverage of the harbour area. Moreover, the sampling locations were chosen with the aim of avoiding areas with known sediment disturbance, such as near shore areas where intensive reclamation activities are taking place and dredged areas. Two grab sediment samples (a and b) were collected within 50 m of each sampling station. The samples of grab sediment were taken with a Van Veen Grab Sampler. A core of sediment was taken at each sampling site using a Kajak gravity corer $^{\circledR}$. The corer was driven into the sediment by gravity, and the sediment core was retained in a PVC tube. The diameter of the PVC coring tube was $70 \mathrm{~mm}$, and about 60 $65 \mathrm{~cm}$ sediment profiles were obtained. Each core was sliced into thin sections at $2 \mathrm{~cm}$ intervals. All of the samples were then stored in polyethylene bags at $4-6^{\circ} \mathrm{C}$ prior to undergoing laboratory analyses. The physical-chemical parameters, including the salinity, $\mathrm{pH}$, and water depth of the harbour waters, were measured in situ using YSI 6600 Sonde. In the laboratory, the size of the particles in the core samples was analyzed using a laser diffraction particle sizer "Coulter® LS100". The organic carbon was determined in freeze-dried sediments, after acidification with $1 \mathrm{M} \mathrm{HCl}$, using a CHNS 
Perkin Elmer 2400 elemental analyzer, with a precision of $0.1 \mu \mathrm{g}$.

\subsection{Trace metal and major element analysis}

For the analysis of the concentrations of metals, sediment samples were freezedried and then ground in an agate grinder until fine particles were obtained. Sediment samples were analyzed for concentrations of major and trace elements using the nitric and perchloric acid digestion method (Ip et al., 2004). About $0.2 \mathrm{~g}$ of the samples of ground sediment were digested with a mixture of $6 \mathrm{ml}$ of nitric acid and $1.5 \mathrm{ml}$ of perchloric acid in a heating block at $50^{\circ} \mathrm{C}$ for $3 \mathrm{~h}, 100^{\circ} \mathrm{C}$ for $1 \mathrm{~h}, 125^{\circ} \mathrm{C}$ for $1 \mathrm{~h}, 150^{\circ} \mathrm{C}$ for $3 \mathrm{~h}, 175^{\circ} \mathrm{C}$ for $2 \mathrm{~h}$ and $190^{\circ} \mathrm{C}$ until completely dry. The residual was then leached with $10 \mathrm{ml}$ of $5 \%(\mathrm{v} / \mathrm{v})$ nitric acid and heated at $70^{\circ} \mathrm{C}$ for $1 \mathrm{~h}$. Trace and major elements in the solutions were determined by inductively coupled plasma-atomic emission spectrometry (ICP-AES, Perkin-Elmer Optima 3300DV). All plastic materials and glassware were soaked in $10 \%$ nitric acid overnight and rinsed thoroughly with deionized water before use. For quality assurance, reagent blanks, sample replicates, and standard reference materials (Buffalo River Sediment-NIST SRM 8704) were used to assess the accuracy and precision of the analysis. The analytical results showed no signs

of contamination and the precision and bias were less than $10 \%$. In the standard reference material (NIST SRM 8704), the recovery rates of trace metals were around 80-105\%. For Fe and Al, the recovery rates were around $50-60 \%$ due to the incomplete digestion of aluminosilicate minerals without hydrofluoric acid (HF).

\subsection{Pb isotopic analyses}


Selected core samples were used for an analysis of the $\mathrm{Pb}$ isotopic composition. Solutions from digested sediment samples were diluted using a 5\% high purity nitric acid solution and analysed for stable $\mathrm{Pb}$ isotope ratios by inductively coupled plasmamass spectrometry (ICP-MS, Perkin Elmer ELAN 6100 DRC $^{\text {plus }}$ ). An instrumental parameter of 150 sweeps/reading was used. The relative standard deviation (RSD) of the ten replicate readings of each sample was $<0.5 \%$. An international standard reference material (the SRM 981 Common Pb Isotopic Standard) from the National Institute of Standards and Technology (NIST) was used for calibration and quality control. It was inserted at the beginning of each run, between every five samples, and at the end of each run, respectively. The average measured ratios of ${ }^{204} \mathrm{~Pb} /{ }^{207} \mathrm{~Pb},{ }^{206} \mathrm{~Pb} /{ }^{207} \mathrm{~Pb}$, and ${ }^{208} \mathrm{~Pb} /{ }^{207} \mathrm{~Pb}$ of the standard reference materials were $0.0645 \pm 0.0002,1.093 \pm 0.002$, and $2.368 \pm 0.004$, respectively. These results were in good agreement with the certified standard values (0.0646, 1.0933, and 2.3704, respectively).

\section{4. ${ }^{210} \mathrm{~Pb}$-dating of sediment cores}

The ${ }^{210} \mathrm{~Pb}$ radiometric technique was used to estimate the chronology of sediment cores. The ${ }^{210} \mathrm{~Pb}$ activities of the samples were determined by measuring the alpha-radioactivity of its granddaughter nuclide ${ }^{210} \mathrm{Po}$. The ${ }^{210} \mathrm{Po}$ was extracted, purified, and self-plated onto a silver disc at $70-80{ }^{\circ} \mathrm{C}$ in $0.5 \mathrm{M} \mathrm{HCl}$, and ${ }^{209} \mathrm{Po}$ was used as the yield monitor and tracer in quantification. The alpha-activity was counted by computerized multi-channel alpha spectrometry with gold-silicon surface barrier detectors. The supported ${ }^{210} \mathrm{~Pb}$ was determined by the alpha activity of the supporting parent, ${ }^{226} \mathrm{Ra}$, via the co-precipitation of $\mathrm{BaSO}_{4}$. In this study, the constant flux/constant sedimentation rate $(\mathrm{CF} / \mathrm{CS})$ model was adopted to calculate the rate of sedimentation 
(Appleby and Oldfield, 1983).

\subsection{Statistical analysis}

A one-way ANOVA and a Student $t$-test were performed to detect whether there were any significant differences in particle sizes and metal concentrations among the sediment samples collected at different sampling periods as well as various sampling locations. A Pearson correlation was performed to identify metal associations in harbour sediments. The critical level for all statistical analyses was carried out at a 95\% confidence interval $(\mathrm{p}<0.05)$. A factor analysis was also applied to identify the major source(s) of metals in the harbour. It was performed on the concentrations of metals in all sediment cores, and Varimax with Kaiser normalization was used as the rotation method in the analysis. All statistical analyses were performed using SPSS ${ }^{\circledR}$ for Window Release 10.1.

\section{Results and Discussion}

\subsection{Physical-chemical properties of harbour sediments}

The depth, salinity, $\mathrm{pH}$ of the water, and total organic carbon (TOC) of surface sediments in Victoria Harbour are given in Figure 2. In general, the water depths in the harbour varied from 7 to $19 \mathrm{~m}$, with increasing from west to east. The $\mathrm{pH}$ was consistent from site to site, with an average of 8.1, which was slightly alkaline and within the normal range for marine water. The salinity in the eastern part was slightly higher than that in the western part, indicating the influence of oceanic water from the west Pacific 
and of the discharge of freshwater from the PRE. The amount of organic carbon in surface sediments ranged from 0.4 to $1.87 \%$, with the highest TOC found in the central part of the harbour and the lowest in the eastern part. A higher amount of TOC in the central part was most likely due to the discharge of untreated urban runoff.

The grain sizes of the sediment cores are shown in Table 1. The sediments displayed significant variations in grain size among different sampling locations $(\mathrm{p}<0.05)$. In general, the finer-grained sediments (with $97 \%<63 \mu \mathrm{m}$ ) were found at B5, whereas coarser sediments (with $52-80 \%<63 \mu \mathrm{m}$ ) were found at B1 and B2, as the latter locations were affected by a strong tidal flow. It is well known that trace metals tend to be adsorbed on the surfaces of particles and that higher concentrations of metals are usually associated with smaller particles (Daskalakis and O’Connor, 1995; Schiff and Weisberg, 1999). In Victoria Harbour, trace metals, including $\mathrm{Cu}, \mathrm{Pb}$, and $\mathrm{Zn}$, showed no significant correlation with the percentage of fine-grained particles in the sediments ( $>>0.05)$ (Figure 3). Therefore, the result indicates that anthropogenic inputs were a more significant control on the distribution of trace metals in the harbour sediments than natural geochemical process.

\subsection{Spatial distribution of trace metals in harbour sediments}

The concentrations of metals in the sediments showed significant differences among the sampling locations, but no major difference during the four sampling periods (ANOVA, $\mathrm{p}>0.05$ ). The concentrations of $\mathrm{Cu}, \mathrm{Pb}$, and $\mathrm{Zn}$ in the four sampling periods were averaged and presented in Table 2. The present findings were consistent with a recent study conducted by the Hong Kong Environmental Protection Department (HKEPD, 2004). According to the Student $t$-test analysis, the degree of $\mathrm{Cu}$ enrichment 
was found to be B2 $~ \mathrm{~B} 3>\mathrm{B} 4>\mathrm{B} 5>\mathrm{B} 1$, while that of $\mathrm{Pb}$ and $\mathrm{Zn}$ was $\mathrm{B} 2 \sim \mathrm{B} 3>\mathrm{B} 4 \sim$ B5 > B1. The central part of the harbour had the largest amounts of $\mathrm{Cu}, \mathrm{Pb}$, and $\mathrm{Zn}$, with mean concentrations of $173,44.3$, and $171 \mathrm{mg} / \mathrm{kg}$, respectively. The significant spatial variation of the metals could be explained by the different urban settings in the territory. The substantial enrichment of trace metals $(\mathrm{Cu}, \mathrm{Pb}$, and $\mathrm{Zn})$ found in the central part (B2 \& B3) was probably caused by the proximity of the location to the most heavily urbanized areas. These areas have a high density of population, a high density of traffic, and are close to old industrial districts. In contrast, B1 sediments with less enrichment of metals are located in an area of strong tidal flushing, with a low density of population and less anthropogenic activity.

The results were compared with the baseline values taken from the measurements in sediment cores from Victoria Harbour, which were typically deeper than $5 \mathrm{~m}$ (Tanner et al., 2000). There was a significant enrichment of trace metals in the central and western parts of the harbour, particularly for $\mathrm{Cu}$ in the central part, which was 20 times higher than the baseline value (Table 2). The high concentrations of $\mathrm{Cu}$ in surface sediments also exceeded the Upper Chemical Exceedance Level of Hong Kong, which may pose some hazards to aquatic life. Further study on the chemical form / bioavailability of the $\mathrm{Cu}$ present in these sediments is required.

The results obtained from the current study are also compared with those from other harbours in the world (Table 3). The levels of $\mathrm{Pb}$ and $\mathrm{Zn}$ in surface sediments of Victoria Harbour are comparable to those of moderately polluted harbours with small catchments and a relatively short history of environmental pollution, such as Darwin Harbour (Peerzada and Rohoza, 1989), Manila Bay (Prudente et al., 1994), and Tolo Harbour (Owen and Sandhu, 2000). In contrast, the $\mathrm{Cu}$ in Victoria Harbour was within the ranges reported in New Bedford Harbour (Stoffers et al., 1977), Baltimore Harbour 
(McGee et al., 1999), and Sydney Harbour (Birch and Taylor, 1999). These are heavily polluted harbours that receive substantial loads of pollutants from river drainages and that have been subjected to pollution for around 100 to 200 years.

\subsection{Temporal distribution of trace metals in harbour sediments}

As sediments in Victoria Harbour are highly mixed by physical processes, such as tidal currents and/or human disturbances, it was only possible to successfully construct the chronology for sediment core B4 using the ${ }^{210} \mathrm{~Pb}$ dating method. The unsupported ${ }^{210} \mathrm{~Pb}$ activities of the core decreased linearly as a function of sediment depth in core B4 while cores B2 and B5 showed non-linear patterns of unsupported ${ }^{210} \mathrm{~Pb}$ (Figure 4). The linear ${ }^{210} \mathrm{~Pb}$ profiles indicated an exponential decline in ${ }^{210} \mathrm{~Pb}$ activity with depth, and this allowed the CF/CS model to be used to calculate the rate of sedimentation (Appleby and Oldfield, 1983). The average sedimentation rate estimated by the CF/CS model in core B4 was $1.2 \mathrm{~cm} / \mathrm{yr}$. The concentration profiles of $\mathrm{Cu}, \mathrm{Zn}$, and $\mathrm{Pb}$ at $\mathrm{B} 1$ to $\mathrm{B} 5$ are shown in Figure 5. The sediment of core B4 showed significant temporal changes in trace metal concentrations, particularly for $\mathrm{Cu}$ and $\mathrm{Zn}$, indicating changing inputs of metal to the harbour during the last few decades. The trend for $\mathrm{Cu}$ closely followed the trend for $\mathrm{Zn}$ in the sediment core, and a significant correlation between these two metals was observed $(p<0.05)$ (Figure 6). This raises the possibility that the two metals probably derived from the same source(s) of industrial emissions and other inputs.

The elevated $\mathrm{Cu}$ and $\mathrm{Zn}$ values in the sediments were observed in the mid-1960s, and significant increases of both metals occurred in the 1970s. The concentrations $\mathrm{Cu}$ and $\mathrm{Zn}$ reached peak values at $33 \mathrm{~cm}$ in the sediment profile corresponding to 1977, 
with maximum concentrations of 91 and $155 \mathrm{mg} / \mathrm{kg}$, respectively. Such a change could be related to the urban and industrial development that was taking place in the territory. Since the 1950s, the manufacturing industry in the territory had grown substantially and remained the largest single contributor to local Gross Domestic Product (GDP) until 1987 (HKGID, 1996). Therefore, intensive industrial activities led to significant inputs of metal in the harbour during the 1950 s to the 1980 s. During that time, the peak concentration of $\mathrm{Cu}$ in the sediments was 8 times higher than the baseline value, and increased to 1.7 times of the $\mathrm{Cu}$ concentration in the deep sediments of the 1950 s. The enrichment of $\mathrm{Cu}$ was most likely related to the large-scale manufacturing of printed circuit boards (PCBs) and electroplating industry in the territory before the 1980s (Yim, 1984, Tanner et al., 2000; HKEPD, 2002).

A decline was observed in metal concentrations in the sediment core from the late 1980s, which could reflect the reduction in industrial activities due to the relocation of industries to mainland China and the setting up of the Chemical Waste Treatment Centre in the territory. The current concentrations of $\mathrm{Cu}$ and $\mathrm{Zn}$ are much lower than the peak values in the 1970 s, the estimated reduction of metals being $45 \%$ and $27 \%$ for $\mathrm{Cu}$ and Zn, respectively.

The trend of the $\mathrm{Pb}$ profile was slightly different from that of $\mathrm{Cu}$ and $\mathrm{Zn}$ at $\mathrm{B} 4$ (Figure 5). The deeper sediments had an average $\mathrm{Pb}$ concentration of $37.5 \mathrm{mg} / \mathrm{kg}$, higher than the baseline concentration in Hong Kong marine sediment (see Table 3). A rise in the concentrations of $\mathrm{Pb}$ to $42-49 \mathrm{mg} / \mathrm{kg}$ occurred during the period 1970 to 1982. Thereafter, the concentrations of $\mathrm{Pb}$ declined to $38.2 \mathrm{mg} / \mathrm{kg}$, although an abrupt increase to $47.8 \mathrm{mg} / \mathrm{kg}$ was observed in 1992 . The surface sediments were characterized by declining concentrations of $\mathrm{Pb}$, with $35.7 \mathrm{mg} / \mathrm{kg} \mathrm{Pb}$ in the topmost sediment. In Hong Kong, a gradual reduction in the amount of $\mathrm{Pb}$ permitted in leaded petrol began in the 
early 1980s, and leaded petrol was totally banned in 1999. Consequently, the increased enrichment of $\mathrm{Pb}$ during the period from 1970 to 1982 in the B4 core can be attributed to the use of leaded gasoline in the territory and to the discharges of industrial wastewater (Yim, 1984; Wong, 1987; Chan et al., 2001).

In general, the distribution of trace metals in Victoria Harbour varied spatially and temporally in the surface and core sediments in the eastern, central, and western parts of the harbour. Spatial variations of trace metals in sediments are likely caused by discharges of sewage, industrial activities, and surface runoff along the coastal areas. The rapid urban and industrial development that has taken place in Hong Kong since the mid-1950s led to a relatively slight increase for $\mathrm{Zn}$ and $\mathrm{Pb}$, with a greater increase for $\mathrm{Cu}$ in subsurface sediments. Subsequent declines in trace metals were observed to have occurred from the late-1980s, due to a gradual reduction in industrial discharges and to better pollution controls in the territory.

\subsection{Potential sources of trace metals in the harbour}

To further elucidate the potential sources of trace metals in Victoria Harbour, the associations of trace elements in sediments were studied using factor analysis. The results of the factor analysis of the total concentrations of metals ( $\mathrm{Al}, \mathrm{Fe}, \mathrm{Mn}, \mathrm{Ca}, \mathrm{Co}$, $\mathrm{Cu}, \mathrm{Ni}, \mathrm{Pb}$ and $\mathrm{Zn}$ ) in the sediment cores are shown in Table 4.

In this analysis, three major components were extracted. They accounted for 83.7\% of the total variance. The first component, which includes $\mathrm{Al}, \mathrm{Fe}, \mathrm{Ca}, \mathrm{Co}$, and $\mathrm{Ni}$, may represent the natural source of the sediments. The second component, including $\mathrm{Cu}$, $\mathrm{Pb}$, and $\mathrm{Zn}$, probably represents anthropogenic sources associated with the discharge of sewage, industrial inputs, and surface runoff in the urban environment. The third 
component consists of $\mathrm{Mn}$ in weak association with $\mathrm{Fe}$ and $\mathrm{Ca}$, and this probably indicating the geochemical process of $\mathrm{Mn}$ and Fe oxides in the sediments.

\subsection{Pb isotopic composition of harbour sediments}

The mean and ranges of the ${ }^{206} \mathrm{~Pb} /{ }^{207} \mathrm{~Pb}$ ratios in the sediments are listed in Table 5. The range of the $\mathrm{Pb}$ isotope ratios varied from 1.154 to 1.197 in these sediments. In general, the ${ }^{206} \mathrm{~Pb} /{ }^{207} \mathrm{~Pb}$ isotopic ratios of the anthropogenic $\mathrm{Pb}$ derived from various $\mathrm{Pb}$ ores were usually lower than those of background geological materials (Croudace and Cundy, 1995; Farmer and Eades, 1996). The natural background of ${ }^{206} \mathrm{~Pb} /{ }^{207} \mathrm{~Pb}$ isotopic ratios in Hong Kong ranged from 1.201 to 1.279 (Ip et al., 2004), while lower values were observed in the harbour sediments. This may provide strong evidence that the $\mathrm{Pb}$ in Victoria Harbour derives from anthropogenic sources. Among the sediment cores, B1 was characterized by relatively low concentrations of $\mathrm{Pb}$ and high ${ }^{206} \mathrm{~Pb} /{ }^{207} \mathrm{~Pb}$ ratios, which were close to the natural background ratios. Thus, the eastern part of the harbour is probably less contaminated with anthropogenic $\mathrm{Pb}$. The ${ }^{206} \mathrm{~Pb} /{ }^{207} \mathrm{~Pb}$ ratios at the $\mathrm{B} 4$ core ranged from 1.171 to 1.190 , whereas noticeably lower Pb isotope ratios with a corresponding increase in the concentrations of $\mathrm{Pb}$ were observed at a depth of $32 \mathrm{~cm}$ (Figure 7). This shift occurred in the sediments that had been deposited since the 1970s, giving a strong indication that inputs of anthropogenic $\mathrm{Pb}$ increased as a result of rapid urban and industrial development in the territory.

To evaluate the potential anthropogenic sources of $\mathrm{Pb}$ in harbour sediments, the ${ }^{206} \mathrm{~Pb} /{ }^{207} \mathrm{~Pb}$ and ${ }^{208} \mathrm{~Pb} /{ }^{207} \mathrm{~Pb}$ ratios of the samples, geological materials in Hong Kong, road dust in Hong Kong, contaminated soils in Hong Kong, and Australian $\mathrm{Pb}$ ore are plotted in Figure 8. The ${ }^{206} \mathrm{~Pb} /{ }^{207} \mathrm{~Pb}$ and ${ }^{208} \mathrm{~Pb} /{ }^{207} \mathrm{~Pb}$ ratios of the harbour sediments and 
the geological materials formed a linear mixing pattern with those of contaminated urban soils and road dust. This probably suggests that the $\mathrm{Pb}$ contamination in the sediments is associated with the input of gasoline lead to the harbour, perhaps from the stormwater runoff of surface soils in the urban setting. The wide range of $\mathrm{Pb}$ isotopic ratios in harbour sediments can most likely be attributed to the mixed sources of gasoline $\mathrm{Pb}$ and other anthropogenic sources in the harbour, e.g. industrial and shipping activities.

\section{Conclusions}

Trace metals in sediments of Victoria Harbour exhibited considerable spatial and temporal variability as a result of various pollutant loadings over the past few decades. The most contaminated site was found in the central part of the harbour, which is close to urban discharge points and former industrial areas. High concentrations of $\mathrm{Cu}$ (up to $460 \mathrm{mg} / \mathrm{kg}$ ) were found in the subsurface sediments in the central part of the harbour. These can be attributed to the intensive industrial activities that took place in the territory and to the discharge of untreated sewage into the harbour from the mid-1950s to the late-1980s. The anthropogenic source of the $\mathrm{Pb}$ was reflected by the lower ${ }^{206} \mathrm{~Pb} /{ }^{207} \mathrm{~Pb}$ ratios in the harbour sediments. The $\mathrm{Pb}$ isotopic signatures showed that the elevated levels of $\mathrm{Pb}$ in the harbour were the mixed product of past gasoline $\mathrm{Pb}$ and $\mathrm{a}$ number of other anthropogenic inputs.

\section{Acknowledgements}

This work was supported by the Area of Excellence (AoE) project under Grant No. AoE/P-04/2004 from the University Grant Council of Hong Kong. We thank the 
two reviewers on their constructive comments and suggestions which are very helpful in improving the quality of the manuscript.

\section{References}

Appleby, P.G., Oldfield, F., 1983. The assessment of 210Pb data from sites with varying sediment accumulation rates. Hydrobiologia 103, 29-35.

Bay, S.M., Zeng, E.Y., Lorenson, T.D., Tran, K., Alexander, C., 2003. Temporal and spatial distributions of contaminants in sediments of Santa Monica Bay, California. Marine Environmental Research 56, 255-276.

Birch, G., Taylor, S., 1999. Source of heavy metals in sediments of the Port Jackson estuary, Australia. The Science of the Total Environment 227, 123-138.

Bothner, M.H., Buchholtz ten Brink, M., Manheim, F.T., 1998. Metal concentrations in surface sediments of Boston Harbor-changes with time. Marine Environmental Research 45, 127-155.

Chan, L.S., Ng, S.L., Davis, A.M., Yim, W.S., Yeung, C.H., 2001. Magnetic properties and heavy metal contents of contaminated seabed sediments of Penny's Bay, Hong Kong. Marine Pollution Bulletin 42, 569-583.

Croudace, I.W., Cundy, A.B., 1995. Heavy metal and hydrocarbon pollution in recent sediments from Southampton water, Southern England: A geochemical and isotopic study. Environmental Science and Technology 29, 1288-1296.

Daskalakis, K.D., O’Connor, T.P., 1995. Normalization and elemental sediment contamination in the Coastal United States. Environmental Science and Technology 29, 470-477.

Duzgoren-Aydin, N.S., Li, X.D., Wong, S.C., 2004. Lead contamination and isotope signatures in the urban environment of Hong Kong. Environmental International 30, 209-217.

Erel, Y., Dubowski, Y., Halicz, L., Erez, J., Kaufman, A., 2001. Lead concentrations and isotopic ratios in the sediments of the Sea of Galilee. Environmental Science and Technology 35, 292-299.

Farmer, J.G., Eades, L.J., Mackenzie, A.B., Kirika, A., Bailey-Watts, T.E., 1996. Stable lead isotope record of lead pollution in Loch Lomond sediments since 1630 A.D. 
Environmental Science and Technology 30, 3080-3083.

Finney, B.P., Huh, C.A., 1989. History of metal pollution in the Southern California Bight: an update. Environmental Science and Technology 23, 294-303.

HKEPD, 1996-2004. Marine Water Quality in Hong Kong. Environmental Protection Department, Hong Kong Government, Hong Kong.

Hong Kong Government, 1995. The shape of things to come - an overview of the role of harbour reclamation in the future development of Hong Kong. Hong Kong Government: Planning. Environment and Lands Branch, pp. 136.

HKGID, 1996. Hong Kong's Manufacturing Industries. Hong Kong Government Industry Department, Hong Kong Government, Hong Kong.

Hornberger, M.L., Luoma, S.N., Green, A., Fuller, C., Anima, R., 1999. Historical trends of metals in the sediments of San Francisco Bay, California. Marine Chemistry 64, 39-55.

Ip, C.C.M., Li, X.D., Zhang, G., Farmer, J.G., Wai, O.W.H., Li, Y.S., 2004. Over one hundred years of trace metal fluxes in the sediments of the Peal River Estuary, South China. Environmental Pollution 132, 157-172.

Lee, S.V., Cundy, A.B., 2001. Heavy metal contamination and mixing processes in sediments from the Humber Estuary, Eastern England. Estuarine, Coastal and Shelf Science 53, 619-636.

McGee, B.L., Fisher, D.J., Yonkos, L.T., Ziegler, G.P., Turley, S., 1999. Assessment of sediment contamination, acute toxicity, and population viability of the estuarine amphipod Leptocheirus plumulosus in Baltimore Harbor, Maryland, USA. Environmental Toxicology and Chemistry 18, 2151-2160.

Morton, B., Wu, S.S., 1975. The hydrology of the coastal waters of Hong Kong. Environmental Research 10, 319-347.

Owen, R.B., Sandhu, N., 2000. Heavy metal accumulation and anthropogenic impacts on Tolo Harbour, Hong Kong. Marine Pollution Bulletin 40, 174-180.

Peerzada, N., Rohoza, W., 1989. Some heavy metals in sediments from Darwin Harbour, Australia. Marine Pollution Bulletin 20, 91-92.

Prudente, M.S., Ichihashi, H., Tatsukawa, R., 1994. Heavy metal concentrations in sediments from Manila Bay, Philippines and inflowing rivers. Environmental Pollution 86, 83-88.

Schiff, K.C., Weisberg, S.B., 1999. Iron as a reference element for determining trace metal enrichment in Southern California coastal shelf sediments. Marine 
Environmental Research 48, 161-176.

Stoffers, P., Summerhayes, C., Forstner, U., Patchineelam, S.R., 1977. Copper and other heavy metal contamination in sediments from New Bedford Harbor, Massachusetts: A preliminary note. Environmental Science and Technology 11, 819-821.

Sturges, W.T., Barrie, L.A., 1987. Lead-206/207 isotope ratios in the atmosphere of north-America as tracers of United States and Canadian emissions. Nature 329, 144-146.

Tanner, P.A., Leong, L.S., Pan, S.M., 2000. Contamination of heavy metals in marine sediment cores from Victoria Harbour, Hong Kong. Marine Pollution Bulletin 40, 769-779.

Wong, C.K.C., Yeung, H.Y., Cheung, Y.H., Yung, K.K.L., Wong, M.H., 2000. Ecotoxicological assessment of persistent organic and heavy metal contamination in Hong Kong coastal sediment. Archives of Environmental Contamination and Toxicology 38, 486-493.

Wong, C.S.C., Li, X.D., 2004. Pb contamination and isotopic composition of urban soils in Hong Kong. The Science of the Total Environment 319, 185-195.

Wong, M.H., 1987. A review on lead contamination of Hong Kong's environment. In Hutchinson, T.C. and Meema, K.M., eds., Lead, Mercury, Cadmium and Arsenic in the Environment, pp. 217-233. John Wiley \& Sons Ltd.

Wong, Y.S., Tam, N.F.Y., Lau, P.S., Xue, X.Z., 1995. The toxicity of marine sediments in Victoria Habour, Hong Kong. Marine Pollution Bulletin 31, 464-470.

Yim, W.W.S., 1981. Heavy metal in marine sediments of Hong Kong. Hong Kong Engineer, 33-39.

Yim, W.W.S., 1984. Geochemical mapping of bottom sediments as an aid to marine waste disposal in Hong Kong. Conservation \& Recycling 7, 309-320.

Yung, Y.K., Yau, K., Wong, C.K., Chan, K.K., Yeung, I., Kueh, S.W., Broom, M.J., 1999. Some observations on the changes of physico-chemical and biological factors in Victoria Harbour and vicinity, Hong Kong, 1988-1996. Marine Pollution Bulletin 39, 315-325.

Zago, C., Giblin, A.E., Bergamasco, A., 2001. Changes in the metal content of surficial sediments of Boston Harbor since the cessation pf sludge discharge. Marine Environmental Research 51, 389-415.

Zhu, B.Q., Chen, Y.W., Peng, J.H., 2001. Lead isotope geochemistry of the urban 
environment in the Pearl River Delta. Applied Geochemistry 16, 409-417. 
Table 1. Grain size distribution in selected samples of sediment from locations B1 to B5 in Victoria Harbour

\begin{tabular}{lcc}
\hline Location & Depth $(\mathrm{cm})$ & $\begin{array}{c}\text { \% fine-grained sediment } \\
(<63 \mu \mathrm{m})\end{array}$ \\
\hline B1 & $4-5$ & 80.1 \\
& $16-18$ & 57.4 \\
& $24-26$ & 71.0 \\
& $36-38$ & 79.4 \\
& $52-54$ & 61.5 \\
\hline B2 & $3-4$ & 51.9 \\
& $7-8$ & 68.8 \\
& $14-16$ & 68.5 \\
& $20-22$ & 61.7 \\
\hline B3 & $2-4$ & 84.9 \\
& $10-12$ & 75.4 \\
& $16-18$ & 96.4 \\
\hline B4 & $24-26$ & 99.9 \\
& $2-3$ & 80.8 \\
& $7-8$ & 80.5 \\
& $14-16$ & 86.9 \\
\hline B5 & $32-34$ & 74.3 \\
& $1-2$ & 95.2 \\
& $5-6$ & 99.9 \\
& $14-16$ & 99.1 \\
\hline & $20-22$ & 99.2 \\
\hline
\end{tabular}


Table 2. Mean ( \pm S.D.) concentrations of $\mathrm{Cu}, \mathrm{Pb}$, and $\mathrm{Zn}(\mathrm{mg} / \mathrm{kg}$, dry weight) in surface sediments of Victoria Harbour collected in December 2004, February 2005, October 2005, and April $2006(n=8)$

\begin{tabular}{|c|c|c|c|}
\hline & $\begin{array}{c}\mathrm{Cu} \\
(\mathrm{mg} / \mathrm{kg})\end{array}$ & $\begin{array}{c}\mathrm{Pb} \\
(\mathrm{mg} / \mathrm{kg})\end{array}$ & $\begin{array}{c}\mathrm{Zn} \\
(\mathrm{mg} / \mathrm{kg})\end{array}$ \\
\hline B1 & $21.2 \pm 4.5^{\mathrm{a}}$ & $19.6 \pm 3.3^{\mathrm{a}}$ & $55.0 \pm 5.3^{\mathrm{a}}$ \\
\hline $\mathrm{B} 2$ & $172 \pm 34.3^{b}$ & $44.0 \pm 17.1^{b}$ & $165 \pm 28.9^{b}$ \\
\hline B3 & $173 \pm 60.5^{b}$ & $44.6 \pm 6.06^{\mathrm{b}}$ & $176 \pm 27.7^{b}$ \\
\hline B4 & $51.4 \pm 14.5^{\mathrm{c}}$ & $30.8 \pm 6.89^{c}$ & $115 \pm 16.3^{\mathrm{C}}$ \\
\hline B5 & $30.2 \pm 8.01^{\mathrm{d}}$ & $30.7 \pm 5.45^{c}$ & $109 \pm 6.76^{\mathrm{C}}$ \\
\hline LCEL $^{1}$ & 65 & 75 & 200 \\
\hline $\mathrm{UCEL}^{2}$ & 110 & 110 & 270 \\
\hline $\mathrm{HKEPD}^{3}$ & $17-230$ & 24-130 & $47-300$ \\
\hline $\begin{array}{l}\text { Background values in Hong } \\
\text { Kong sediments }\end{array}$ & 11 & 32 & 67 \\
\hline \multicolumn{4}{|c|}{$\begin{array}{l}\text { The small letters in the columns stand for statistical significance at the } 0.05 \text { level with a Student } t \text {-test } \\
\text { among the sampling locations. } \\
{ }^{1} \text { LCEL Lower Chemical Exceedance Level for assessments of sediment quality in Hong Kong. Biological } \\
\text { effects would be observed above this level (HKEPD, 2004). } \\
{ }^{2} \text { UCEL Upper Chemical Exceedance Level for assessments of sediment quality in Hong Kong. Adverse } \\
\text { biological effects would be observed above this level (HKEPD, 2004). } \\
{ }^{3} \text { HKEPD Data from an HKEPD sediment monitoring programme conducted in } 2003 \text { (HKEPD, 2004). } \\
{ }^{4} \text { Tanner et al., } 2000\end{array}$} \\
\hline
\end{tabular}


Table 3. Metal concentrations in the sediments of other polluted harbours (mg/kg, dry weight)

\begin{tabular}{lccc}
\hline Location & $\mathrm{Cu}$ & $\mathrm{Pb}$ & $\mathrm{Zn}$ \\
Boston Harbour, U.S.A. $^{1}$ & $7-142$ & $18-263$ & $39-414$ \\
New Bedford Harbour, U.S.A. $^{2}$ & $117-3136$ & $104-616$ & $315-1550$ \\
Baltimore Harbour, U.S.A. $^{3}$ & $9.5-396$ & $1.0-349$ & $40-2105$ \\
Sydney Harbour, Australia $^{4}$ & $9.3-1053$ & $38-3604$ & $108-7622$ \\
Darwin Harbour, Australia $^{5}$ & $16-32$ & $24-91$ & $103-270$ \\
Manila Bay, Philippines $^{6}$ & $32-118$ & $6.0-95$ & $60-329$ \\
Tolo Harbour, Hong Kong $^{7}$ & $21-84$ & $48-144$ & $100-270$ \\
Victoria Harbour, Hong Kong $^{8}$ & $16-280$ & $21-85$ & $52-221$ \\
${ }^{1}$ Zago et al., 2001 & & & \\
${ }^{2}$ Stoffers et al., 1977 & & & \\
${ }^{3}$ McGee et al., 1999 & & & \\
${ }^{4}$ Birch and Taylor, 1999 & & & \\
${ }^{5}$ Peerzada and Rohoza, 1989 & & &
\end{tabular}


Table 4. Result of the factor analysis on total concentrations of metals in B1 to B5 sediment cores $(n=116)$

\begin{tabular}{lccc} 
& & Principle loading factors & \\
\% of variance & PC 1 & PC 2 & PC 3 \\
\hline $\mathrm{Cu}$ & $37.3 \%$ & $28.9 \%$ & $17.6 \%$ \\
$\mathrm{Ni}$ & -0.083 & $\mathbf{0 . 7 3 2}$ & -0.508 \\
$\mathrm{~Pb}$ & $\mathbf{0 . 7 8 2}$ & 0.202 & -0.276 \\
$\mathrm{Zn}$ & 0.051 & $\mathbf{0 . 9 4 9}$ & -0.004 \\
$\mathrm{Al}$ & 0.222 & $\mathbf{0 . 8 6 3}$ & -0.248 \\
$\mathrm{Fe}$ & $\mathbf{0 . 8 7 0}$ & 0.351 & -0.019 \\
$\mathrm{Mn}$ & $\mathbf{0 . 8 4 2}$ & -0.203 & 0.449 \\
$\mathrm{Co}$ & -0.002 & -0.190 & $\mathbf{0 . 9 2 4}$ \\
$\mathrm{Ca}$ & $\mathbf{0 . 9 3 3}$ & -0.188 & 0.181 \\
& $\mathbf{- 0 . 5 9 4}$ & -0.371 & 0.300
\end{tabular}


Table 5. Mean ( \pm S.D.) of ${ }^{206} \mathrm{~Pb} /{ }^{207} \mathrm{~Pb}$ ratios and range of $\mathrm{Pb}$ concentrations and ${ }^{206} \mathrm{~Pb} /{ }^{207} \mathrm{~Pb}$ ratios in sediment cores, B1 to B5, of Victoria Harbour

\begin{tabular}{cccc}
\hline & $\begin{array}{c}\text { Range of Pb concentration } \\
(\mathrm{mg} / \mathrm{kg})\end{array}$ & Mean ${ }^{206} \mathrm{~Pb} /{ }^{207} \mathrm{~Pb}$ & Range ${ }^{206} \mathrm{~Pb} /{ }^{207} \mathrm{~Pb}$ \\
\hline B1 $(\mathrm{n}=5)$ & $25.9-32.4$ & $1.181 \pm 0.005$ & $1.173-1.185$ \\
B2 $(\mathrm{n}=5)$ & $35.1-56.9$ & $1.175 \pm 0.006$ & $1.168-1.182$ \\
B3 $(\mathrm{n}=5)$ & $39.8-52.2$ & $1.174 \pm 0.005$ & $1.168-1.180$ \\
B4 $(\mathrm{n}=22)$ & $33.2-52.7$ & $1.182 \pm 0.012$ & $1.170-1.190$ \\
B5 $(\mathrm{n}=5)$ & $33.7-45.0$ & $1.175 \pm 0.015$ & $1.154-1.189$ \\
\hline
\end{tabular}




\section{Figure Captions}

Figure 1. The sampling locations, B1-B5, in Victoria Harbour

Figure 2. Physical parameters of the water (water depth, salinity, and $\mathrm{pH}$ ) and the total organic carbon (TOC) of surface sediments in Victoria Harbour at different sampling periods

Figure 3. The correlation of $\mathrm{Cu}, \mathrm{Zn}$, and $\mathrm{Pb}$ with the percentage of fine-grained particles in Victoria Harbour

Figure 4. Results of ${ }^{210} \mathrm{~Pb}$ dating in sediment cores B2, B4, and B5 of Victoria Harbour

Figure 5. Temporal distribution of $\mathrm{Cu}, \mathrm{Zn}$, and $\mathrm{Pb}$ in core sediments, $\mathrm{B} 1$ to $\mathrm{B} 5$, of Victoria Harbour (Core B4 with the estimated date)

Figure 6. The correlation between $\mathrm{Cu}$ and $\mathrm{Zn}$ in sediments of core B4

Figure 7. ${ }^{206} \mathrm{~Pb} /{ }^{207} \mathrm{~Pb}$ ratios and $\mathrm{Pb}$ concentrations $(\mathrm{mg} / \mathrm{kg}$ ) in the dated sediment core $\mathrm{B} 4$ of Victoria Harbour

Figure 8. Relationship between ${ }^{208} \mathrm{~Pb} /{ }^{207} \mathrm{~Pb}$ and ${ }^{206} \mathrm{~Pb} /{ }^{207} \mathrm{~Pb}$ in the sediments of Victoria Harbour and those from known sources in Hong Kong 


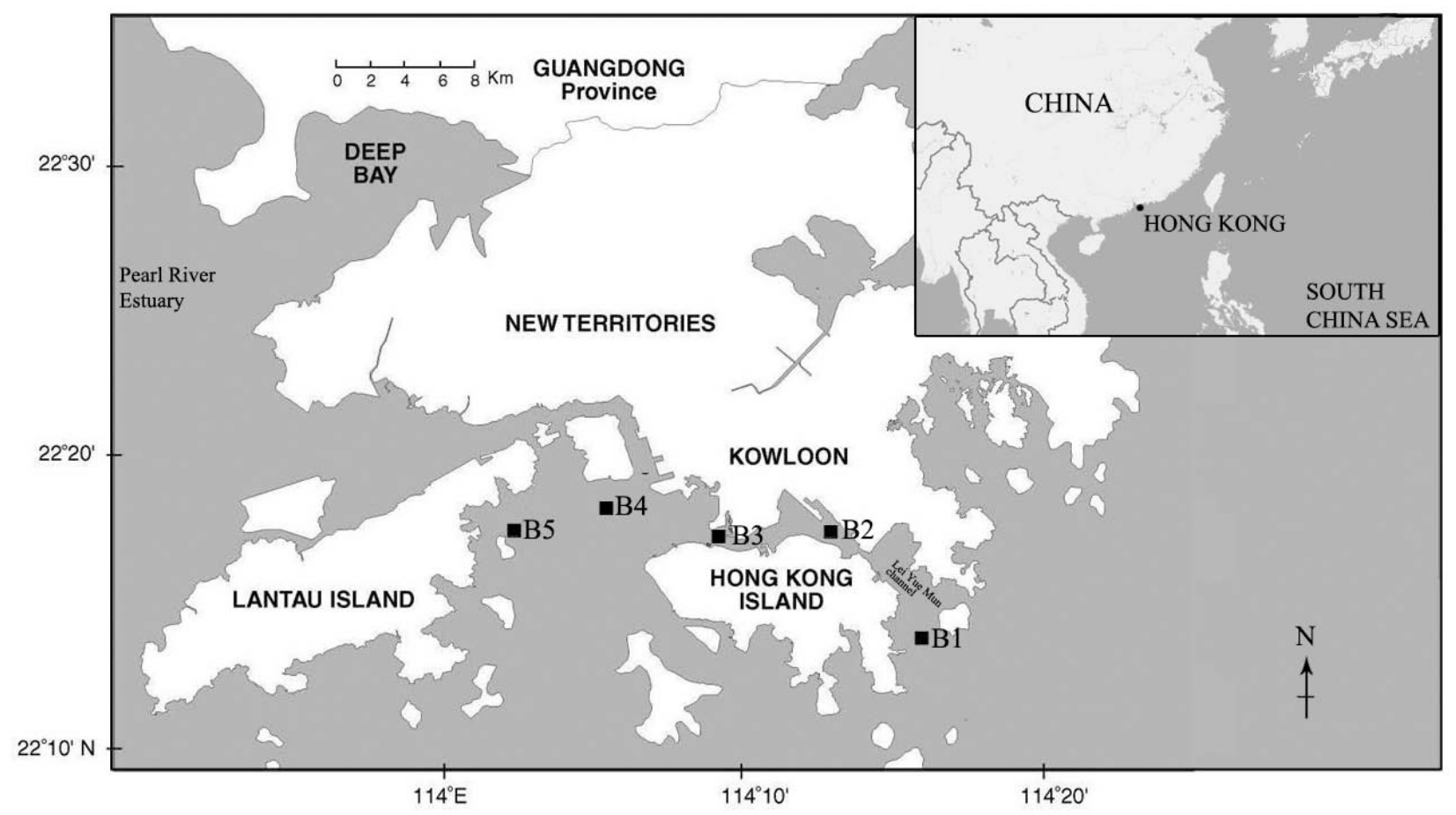

Figure 1. The sampling locations, B1-B5, in Victoria Harbour 
Water Depth (m)

๑Dec-04 가 Feb-05 日Oct-05 口Apr-06

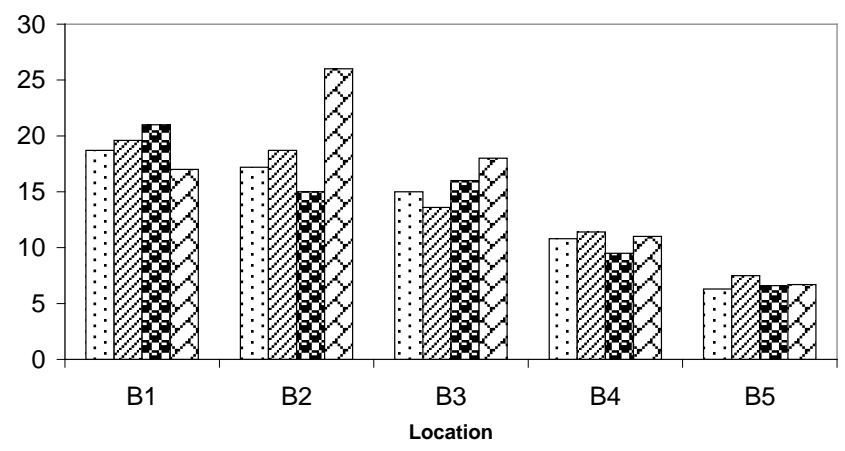

$\mathrm{pH}$

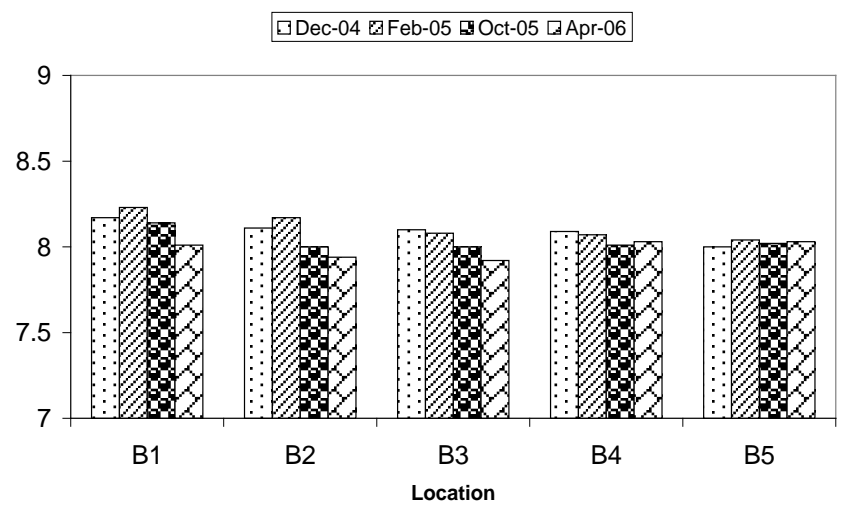

S\&lähitity(po\%)

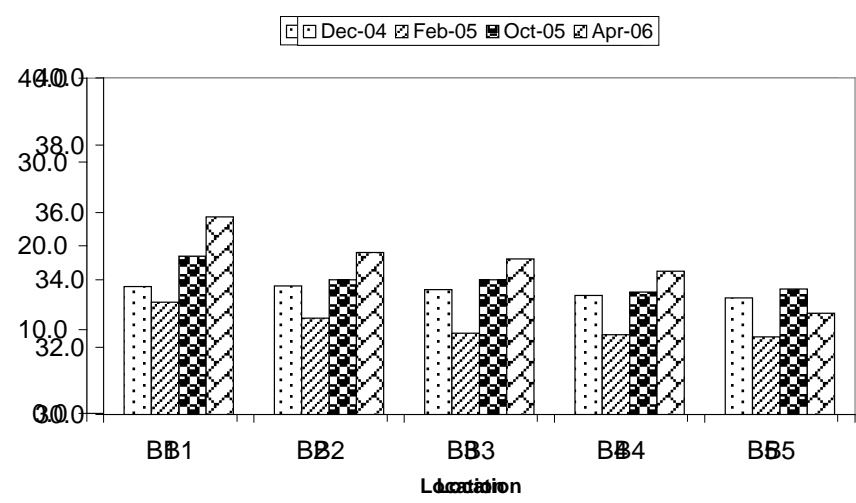

TOC\%

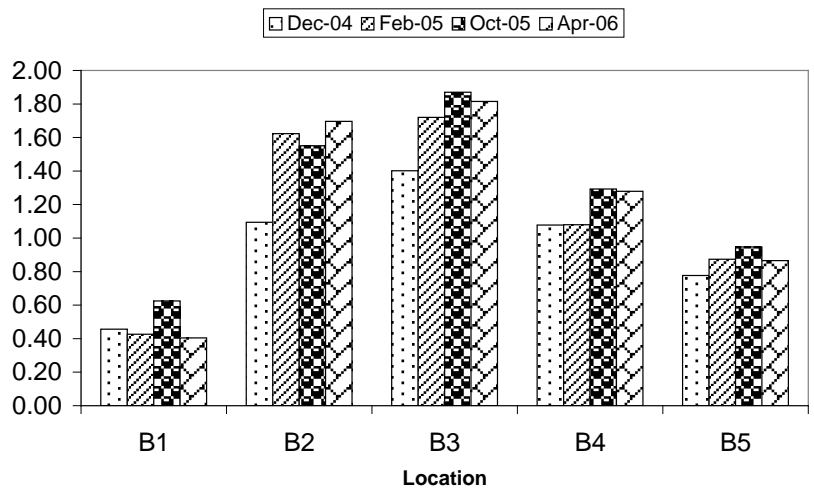

Figure 2. Physical parameters of the water (water depth, salinity, and $\mathrm{pH}$ ) and the total organic carbon (TOC) of surface sediments in Victoria Harbour at different sampling periods 
Total metal concentrations vs. $\%$ of fine-grained sediments

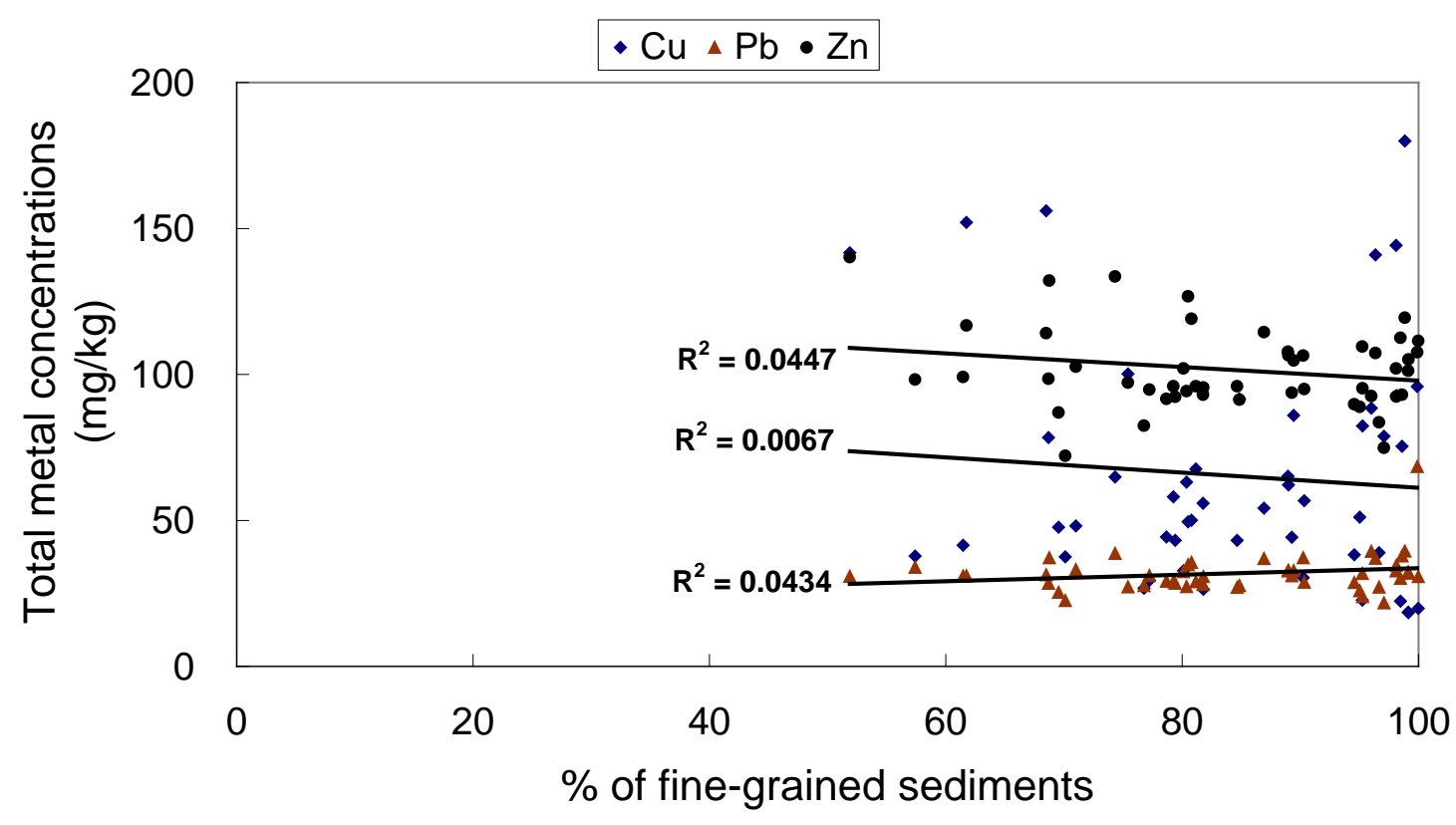

Figure 3. The correlation of $\mathrm{Cu}, \mathrm{Zn}$, and $\mathrm{Pb}$ with the percentage of fine-grained particles in Victoria Harbour 


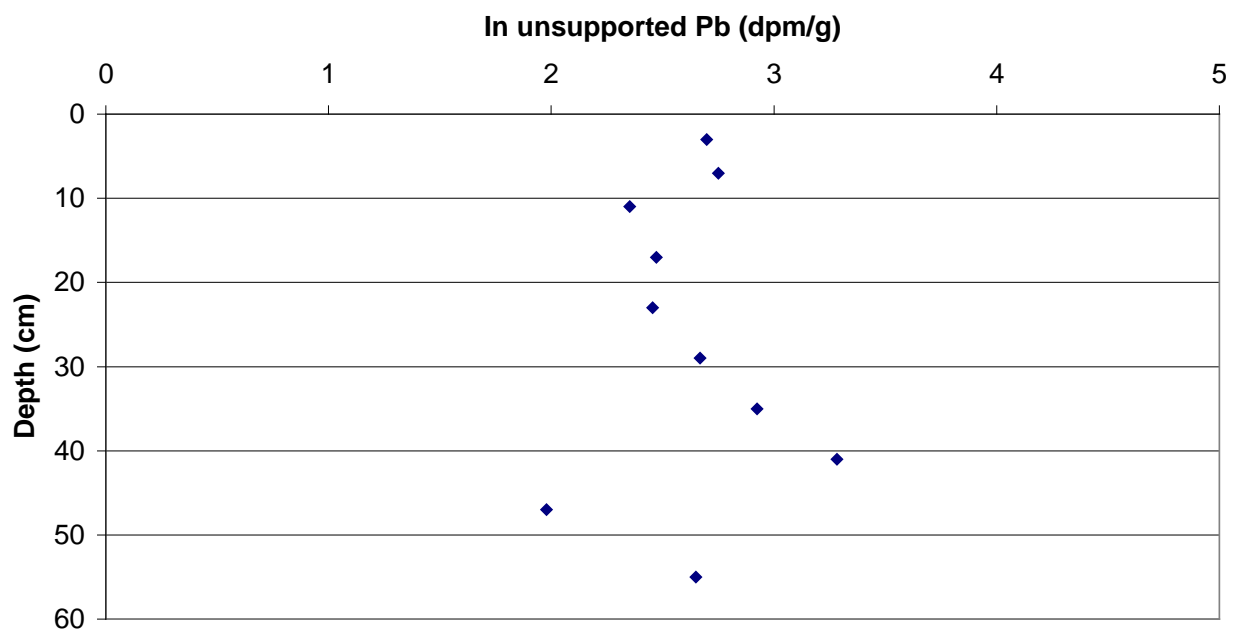

B4
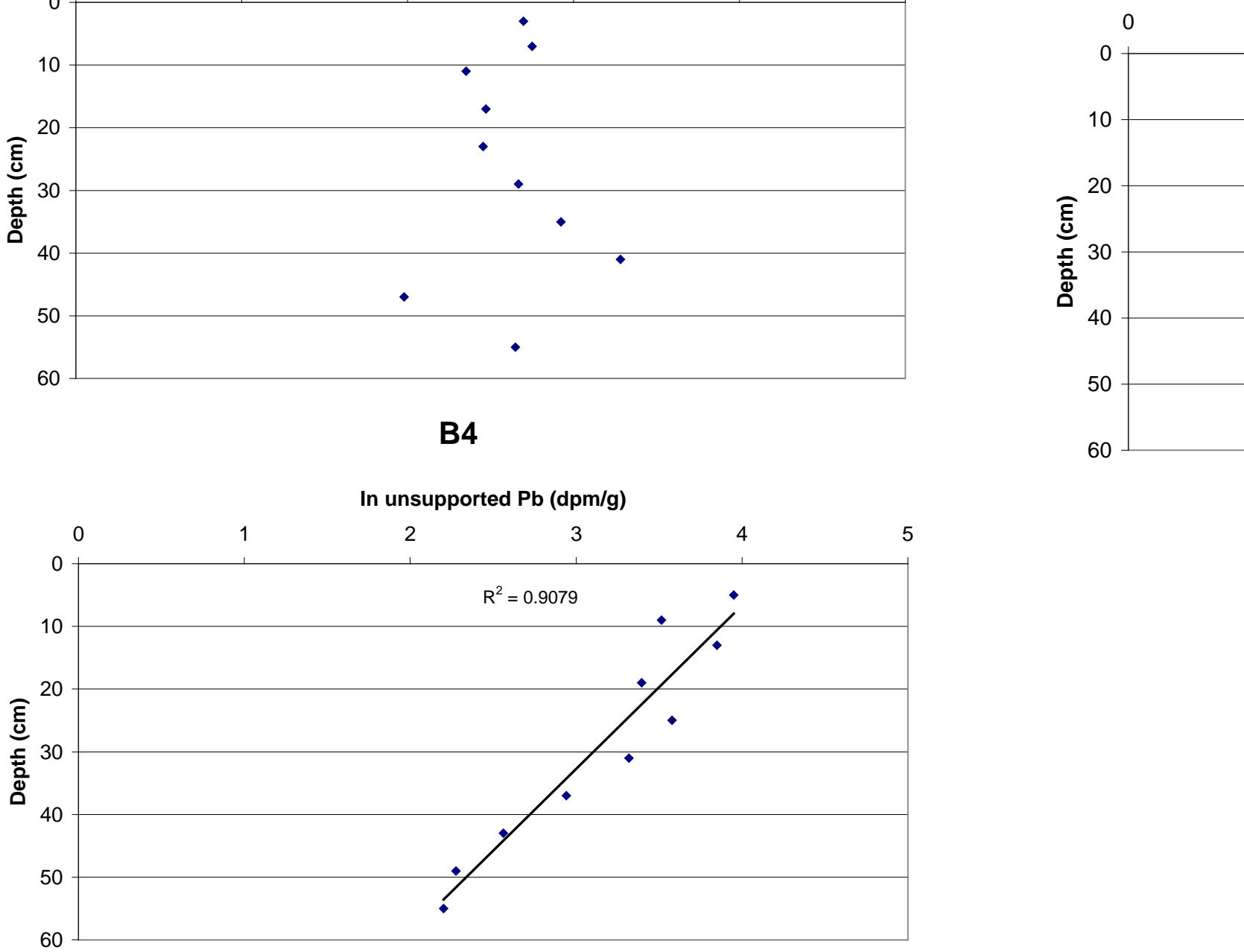

B5

In unsupported $\mathrm{Pb}(\mathrm{dpm} / \mathrm{g})$

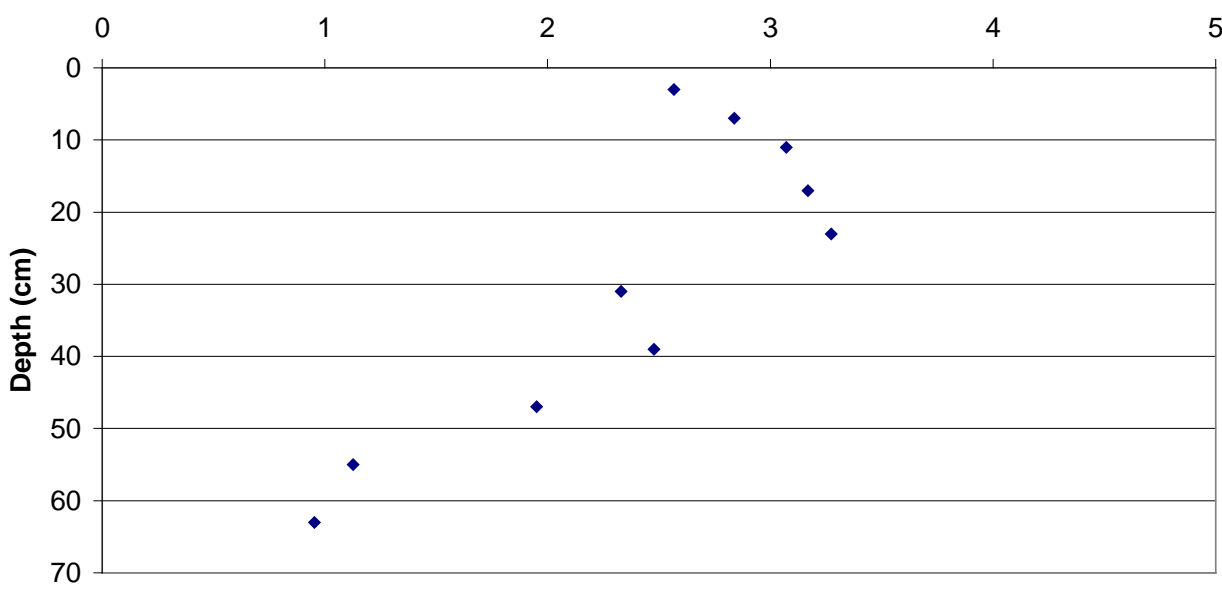

Figure 4. Results of ${ }^{210} \mathrm{~Pb}$ dating in sediment cores B2, B4, and B5 of Victoria Harbour 

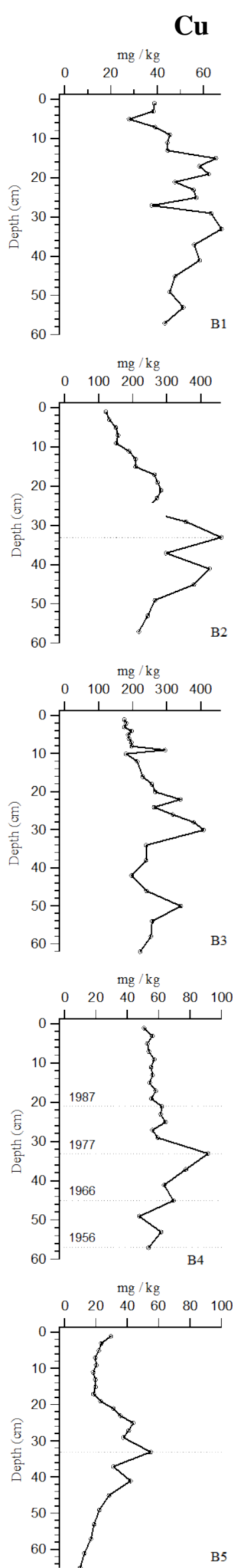

Zn
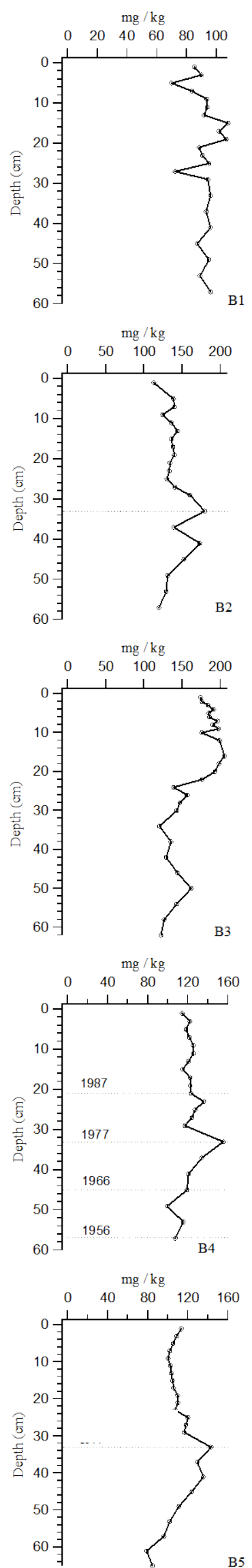

$\mathbf{P b}$
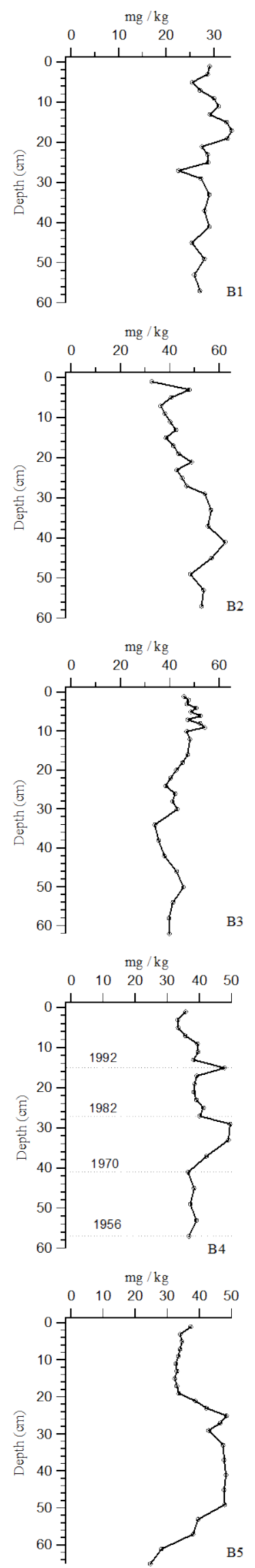

Figure 5. Temporal distribution of $\mathrm{Cu}, \mathrm{Zn}$, and $\mathrm{Pb}$ in core sediments, $\mathrm{B} 1$ to $\mathrm{B} 5$, of Victoria Harbour (Core B4 with the estimated date) 
Cu vs. Zn

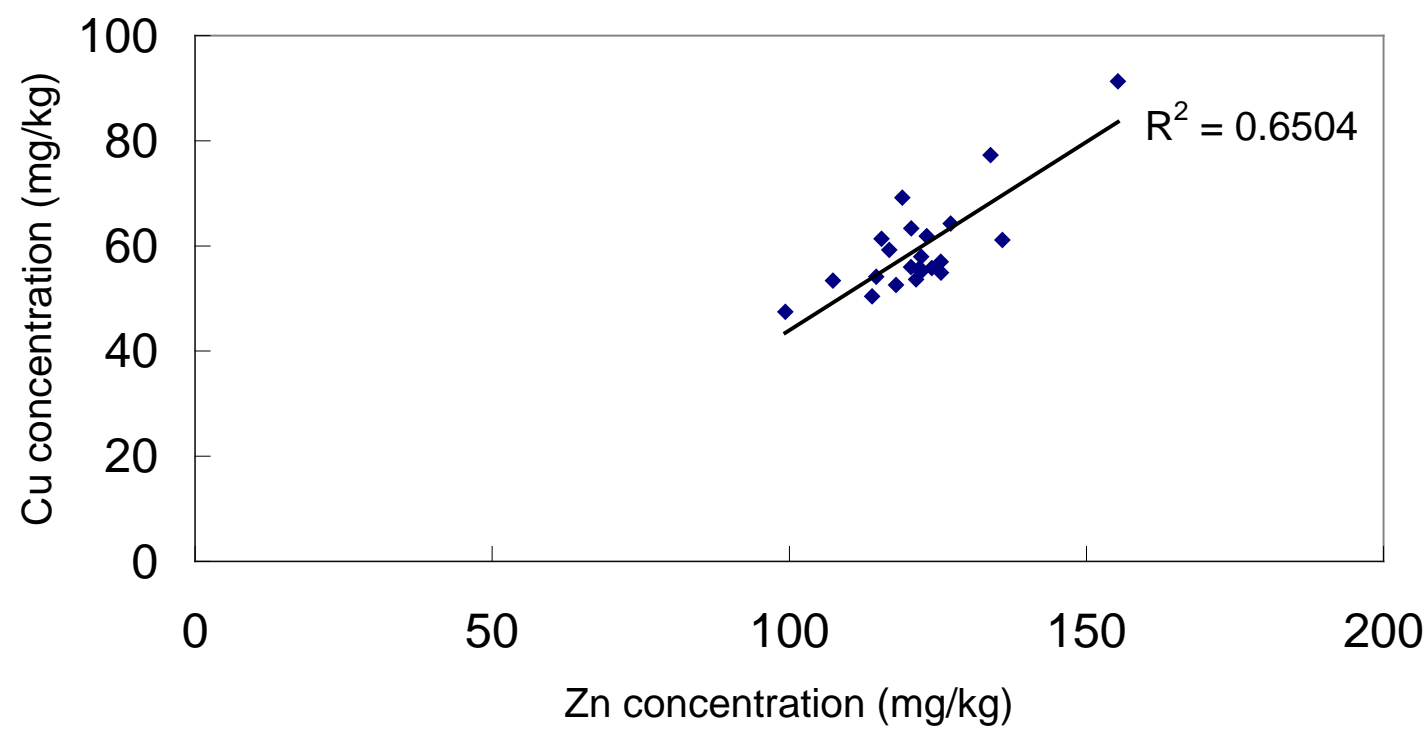

Figure 6. The correlation between $\mathrm{Cu}$ and $\mathrm{Zn}$ in the dated sediment core B4 


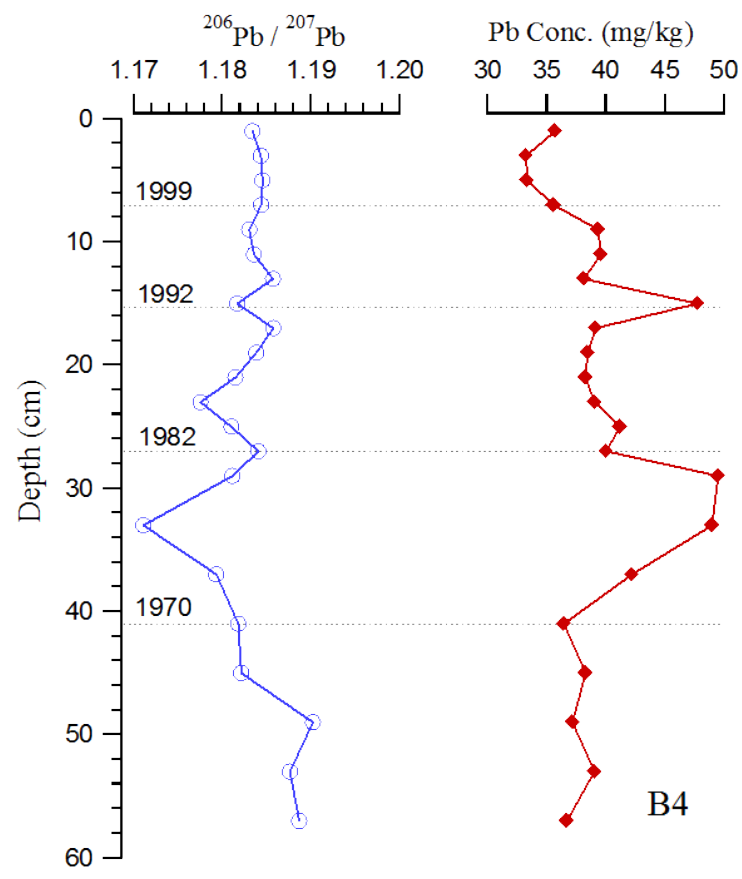

Figure 7. ${ }^{206} \mathrm{~Pb} /{ }^{207} \mathrm{~Pb}$ ratios and $\mathrm{Pb}$ concentrations (mg/kg) in the dated sediment core $\mathrm{B} 4$ of Victoria Harbour 


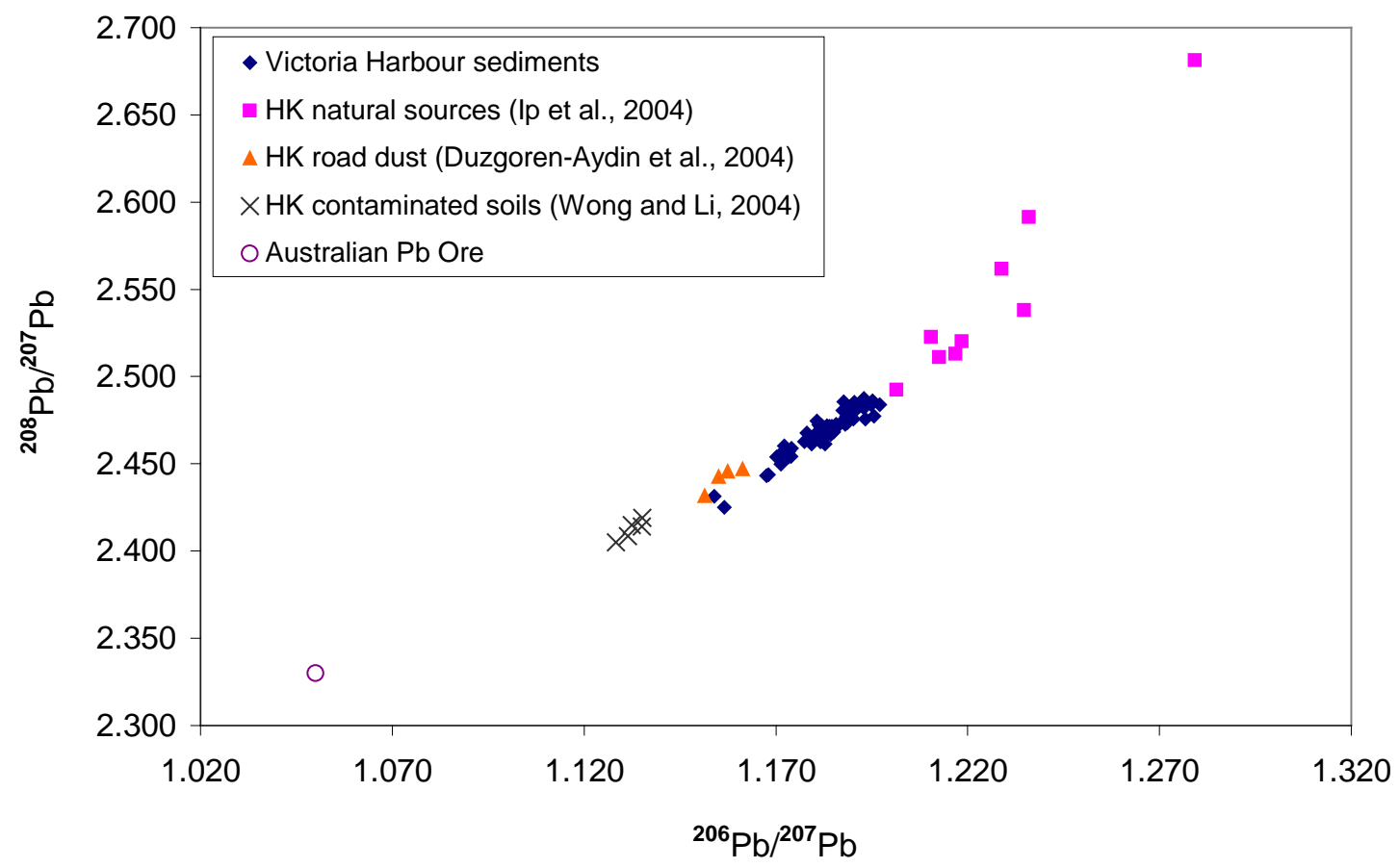

Figure 8. Relationship between ${ }^{208} \mathrm{~Pb} /{ }^{207} \mathrm{~Pb}$ and ${ }^{206} \mathrm{~Pb} /{ }^{207} \mathrm{~Pb}$ in the sediments of Victoria Harbour and those from known sources in Hong Kong 